\title{
Soyo Practice: Revitalization of Local Wisdom Values in The Community Empowerment of The Modern Management Era
}

\author{
Misbahul Munir, Basir Sagena, and Maretha Ika Prajawati
}

ABSTRACT

\begin{abstract}
The mutual help or soyo practice, which has relevance in modern management systems, is an effort to strengthen the local wisdom values in urban communities that tend to rely on cultural mechanisms. This research aims to show the cultural mechanism that still survives in Javanese urban communities concerning modern management systems development. Meanwhile, the analysis performed was based on data obtained through interviews, observation, and documentation methods. The research showed that soyo is a local tradition that emphasizes the survival of solidarity bonds and mutual help or ta'awun. Furthermore, the practice describes the efforts to maintain community cohesion and solidity amid life's complexities. The mutual help principle in soyo has also proven to assist the community in achieving goals without fully relying on economic capital and other parties' intervention, especially from the state. Therefore, a modern management system should be open to the local wisdom values in reflecting how to achieve these goals.
\end{abstract}

Keywords: soyo practice, local wisdom, ta'awun, cooperation, modern management.

\section{INTRODUCTION}

The mutual help or soyo practice that has been identified with rural communities is seldom true as these traditions are also found in urban societies. Meanwhile, the practice by the Pesanggrahan Hamlet community in Batu City shows the proper maintenance and continuity of social ties up till now. This tradition is based more on fulfilling people's needs without involving other parties, especially the state, and in 2019, the head of the Pesanggrahan Hamlet records revealed that at least twenty (20) soyo events occurred every month. Although these traditions were not reliant on patterned work management practices, such as the modern systems with written work distribution, they showed community solidity in managing human resources and becoming more independent.

Many experts have conducted studies that discuss the local wisdom contribution and, three trends have been generally associated with this theme. First, researches that place local wisdom as a mechanism in dealing with various conflicts in the community [5], [36], [7]. According to [7] local wisdom owned by the community is useful as a powerful conflict resolution for people with heterogeneous religious and ethnic backgrounds. Second, studies that see local wisdom as the social foundation for fostering togetherness [27], [6], [43] and place it at a philosophical level. Third, researches that discuss the challenges where relevant studies were conducted by [31], [32]. Although these three trends revealed that the local wisdom was still performed by rural communities, the implementation by
Submitted : February 2, 2021

Published : February 22, 2021

ISSN: 2507-1076

DOI: $10.24018 /$ ejbmr.2021.6.1.728

Misbahul Munir*

UIN Maulana Malik Ibrahim Malang, Indonesia.

(e-mail: misbahu107@gmail.com)

Basir Sagena

Universitas Indonesia, Indonesia.

(e-mail: basir@ui.ac.id)

Maretha Ika Prajawati

UIN Maulana Malik Ibrahim Malang, Indonesia.

(e-mail: maretha@uin-malang.ac.id)

*Corresponding Author

urban communities has not been specifically examined.

This study aims to provide an in-depth analysis of the soyo practice that is still being performed in the Pesanggrahan Hamlet urban community, Batu City. It is a form of mutual cultural help between communities that is generally performed by rural inhabitants. For further analysis of this matter, three questions were asked, and the first queried the occurrence and survival of soyo activities in a society that had adopted a modern management system. The second asked how the philosophical foundation and local wisdom had become the basis for this practice and also how it was sustained in the modern management era. Conversely, the third inquired how the soyo tradition influenced the community's independence in meeting their needs and solving problems. These three questions were answered as a way to find arguments. Also, the existence of this cultural mechanism in a society that was uninterrupted by the state or policies was explained.

Local wisdom in the soyo practice provides a chance for the new creative development of the Pesanggrahan Hamlet people to be less dependent on external assistance, especially from the state. This is not only a medium to show commitment to helping each other, but also to create and grind Islamic values in non-religious social practices. Besides having strong cultural roots, the sustainability of soyo also has a deep basis for religious legitimacy. 


\section{LITERATURE REVIEW}

\section{A. Local Wisdom}

Local wisdom is defined as the community understanding that becomes a reference in everyday life [20] and includes strategies in solving various problems. These issues concern the need for tolerance and the brotherhood principle that creates harmonized diversity [3]. This understanding comes from past experiences, which were adopted, and then handed over to the next generation through an evolutionary process [44]. According to [18] it is formed from knowledge, understanding, and insight, as well as customary beliefs and ethics. Meanwhile, there are several forms of local wisdom, which include the philosophy of life, attitude, and guidelines [26]. [9] emphasized the importance of as part of a cultural element that should be explored, studied, and revitalized because the essence is significant in strengthening the foundation of national identity in globalization. Corresponding with a study by [37], the value of this wisdom becomes a guide in attitude, which then functions as an alternative in shaping cultured human beings and noble characters. Local wisdom that is associated with social identity and becomes knowledge is appropriate in building a country to ensure national development performed through education, such as incorporating cultural lessons in schools [28].

In Silalahi 1 Village, North Sumatra, there is local wisdom in preserving Lake Toba as a sacred place with the placement of various restrictions. These include prohibitions on wearing jewelry, spitting, bathing after six o'clock, bringing and eating pork or dog meat, bathing naked in the lake, bursting out laughing, and women unpacking their long hair. These restrictions are placed due to the belief that the entire Lake Toba area is controlled by Bibi (Namboru) and should, therefore, be sanctified [15]. Meanwhile, the Ngata Toro community in Southeast Sulawesi has managed the forest by dividing the area into several zones, such as balingke, arewana, oma, pahawa pongko, ngkiki, wana, and pangale. These divisions are accompanied by regulations related to product-based forest conservation and sustainable use and also integrate the values of balance, cooperation, and reciprocity [42]. In Indonesia, local wisdom can be implemented as a socio-cultural mechanism contained in the traditions. Subsequently, this wisdom has proven to be more effective in gathering brotherhood and solidarity between owners that have been institutionalized and crystallized in the social and cultural order. In Manggarai, Lejong Tau, East Nusa Tenggara Province, a culture of solidarity between migrants that originated from this region has long existed and is preserved based on local enthusiasm in overseas social life [21].

\section{B. Empowerment}

Empowerment is an elusive, contested, and ambiguous concept. Although there are several definitions, this word comes from an idea that refers to the process of change from helplessness to power [1]. Empowerment was interpreted by two schools of thought, where the first was based on community agency and the ability to control their lives, and the second was founded on political and economic ideas in making institutions more responsive to local societies [10]. The dimensions that form this process consist of knowledge and understanding, personal control, identity, joint decision making, as well as the involvement of others [2]. An example of how this concept is implemented involves the transfer of top-down power from a more to a less empowered person or people [4]. This approach is performed for development goals with an emphasis on direct democracy, local independence, social learning, and autonomy in government decision-making [4]. Furthermore, the empowerment goal is achieved from the transfer of various strength types from higher to lower levels [10].

Community empowerment based on local cultural wisdom is necessary to empower people through the utilization of various resources in a sustainable manner. This empowerment is realized in various forms, such as entrepreneurship [12], local tourism [38], and food resource management [29]. Building independence by utilizing natural resources, local wisdom, and assistance from various parties is needed for empowerment. Although every society has strength, it is either inexplicitly known or the people are unaware, which further emphasizes the recognition of the subject and abilities of a community. A successful empowerment process is marked by the community's ability to analyze a problem, then plan, implement, and evaluate a program to increase sustainable independence. Therefore, it should be ensured that empowerment actors have good knowledge and skills to support the success of the program [40]. [24] found several factors that influence empowerment success, especially of the rural women in the Salahutu District area. These indigenes were observed to rely on the roles of the government, cooperatives, capital, local community organizations, education, entrepreneurial spirit, mentoring, socio-culture, and NGOs.

\section{Local Institutions}

Local institutions are formal and informal social mechanisms where community members collectively decide the best method for managing their needs [23]. The formal institutions are linked to official channels, particularly government bureaucracy, while the informal equivalents refer to socially shared rules such as community or cultural norms, which are mostly unwritten [23]. Local institutions regulate people's way of life, play an important role in economic growth [41] and can provide their knowledge and capacity to implement policy initiatives. They mediate external interventions into local contexts and articulate between social, political, and extra-local processes [19]. The role of local institutions is a social capital formation that can improve household welfare through various information on collaborative work and collective decision making [19]. Ignorance of local institutions in managing group resources will create numerous problems, such as the struggle for land rights in local communities, which is a common occurrence [8].

Many cases have shown the important roles of local institutions, such as fishing communities in Cambodia that handle small-scale projects and deal with local tourism affairs [25]. In the mining community, local institutions, which in this case is the village head, mediate negotiations with companies to protect their interests, as well as provide adequate compensation and benefit from royalties and socioeconomic development [22]. In Indonesia, one of the most 
renowned of these institutions is the subak in Bali, in which the customary law community has social agrarian and religious characteristics. Subak is regulated by the Bali Provincial Regulation No. 3 of 2001 concerning Traditional Villages, which protects customary lands. Hence, ownership is not eroded by parties outside the customary village [39]. Also, some institutions formed in the genten tradition at Tengger, East Java perform the tradition of assisting others, by helping people affected by disaster, celebration, and so on [17]. Therefore, local institutions together with community participation have contributed to the sustainable development framework [14].

\section{Methodology}

The research was conducted in Pesanggrahan Hamlet, Batu City in the East Java Province of Indonesia, and this location was determined because the region has remained communal even though it is an urban area geographically. Although the Hamlet is located between areas where the community culture has changed, the social ties in this vicinity still maintain the kinship pattern, even without blood relations. Furthermore, this area has a more massive soyo activity intensity compared to other hamlets in Batu City.

The data analyzed and used as the basis for the research were obtained from the field through observation, interviews, and literature study methods. Meanwhile, the observation was focused on the soyo implementation, which involved many people with various social backgrounds. Interviews were conducted with community leaders, the public, and specifically people that had been the foundation of soyo, such as wood and stone carpenters. Furthermore, the informants were selected based on the consideration that they had been directly involved and functioned in the sustainability of this practice in Pesanggrahan Hamlet. The data obtained from the literature was used as a comparison from the two initial methods.

Subsequently, the data was collected through several methods and classified according to the tendency and need to answer the questions posed. After grouping, it was contextualized through interpretive analysis techniques, which made the position clearer. Then, a paper that had been juxtaposed with data obtained from expert statements contained in journal articles and books was drafted.

\section{RESULT}

\section{A. The Soyo Practice in the Pesanggrahan Community}

The soyo practice is not only a local tradition that emphasizes the survival of solidarity and the tradition of mutual help or ta'awun, but also shows an effort to maintain community cohesion and solidity amid current modern life complexities. So far, soyo has been practiced at the community level and also in families through money, goods, and manpower assistance to relatives that are building houses, as disclosed by Slamet:

"Donations in the form of money or goods are usually given by members of the community with a fairly wellestablished economic capacity, or are indeed busy with other matters... But those that have little money generally donate energy..." (Interview, in Pesanggrahan, 2020).

The statements above indicate an effort to ease the burden among family members that need money to complete the construction of their homes. At a broader level, the involvement of a person in the process of building a resident's house is based on a spirit of sincerity without expecting anything in return. Assistance in the form of money and manpower came without formal information, and dissemination through word of mouth was able to spread the knowledge that a resident was to build a house. Therefore, other community members came with their respective assistance without being coordinated. For instance, in house casting, some people sent building materials, some donated money, while others came to help by contributing labor. Sumadi, one of the community leaders in Pesanggrahan Village said:

"These villagers possess strong cohesiveness, are not selfish, live in harmony, and make efforts to help their neighbors. Meanwhile, those that have no money assist with their energy because when has a need, the neighbors will be the first to help" (Interview at Pesanggrahan, 2020).

A similar statement was made by Anam that:

"...I remember when I was a child, my parents' house was built through soyo too. Hence, in my opinion, it has become a habit for people here... some donate money, bricks, wood, while some contribute energy..." (Interview at Pesanggrahan, 2020).

This explains the community's desire to ease the burdens of others through social mechanisms that were difficult to accept in modern managerial terms. Rewards, such as fees paid for professional work practices, are in contrast to the soyo tradition, which is based on the desire to help others, and also on noble values that exist within the community.

\section{B. The Philosiphical Foundation and Local Wisdom in Soyo Practice}

Three values that form the basis for the soyo practice in the Pesanggrahan community. The first is religiosity, which is seen in the tradition of mutual helping as contained in QS Al-Maidah verse 2 "...Cooperate with one another in goodness and righteousness, but not in sin and transgression..."

Sumadi, the elder of this community, also expressed the enforcement of religious values in soyo by saying that:

"Religion teaches that whoever plants goodness will definitely reap the results later" (Interview at Pesanggrahan, 2020).

The second value is togetherness, which is also contained in the soyo practice and is difficult to find in certain communities, such as in urban areas. Kamit, one of the residents said:

"Generally, urban people always think about themselves and very rarely want to think about others or be involved in mutual cooperation, even when it is more practical" (Interview at Pesanggrahan, 2020).

A similar statement was made by Slamet that:

"At first glance, Soyo seems simple, like casting the Sunan Ampel TPQ (Al-Quran Education Park) floor. But behind this simplicity, there is an element of mutual cooperation and the values of togetherness, unity, and self- 
sacrifice. The most important component is cooperation, which contains brotherhood, a term that is spoken as 'kerjarasa' meaning cooperation with feelings" (Interview at Pesanggrahan, 2020).

The third value is happiness as the meetings in soyo show togetherness, cooperation, and "kerjarasa" which creates personal joy for most of the residents. Mudik, a local that is always present and helps when other residents build houses said:

"...Alhamdulillah, we still encounter soyo in our residents almost weekly, as they voluntarily help and have great concern for each other even without payment. It feels great to help and be of benefit to others together..." (Interview at Pesanggrahan, 2020).

Qodir expressed a similar sentiment:

"I am very happy to see people's desire to participate in soyo. As a builder, I was helped greatly during the completion of a house. Normally, if a house is erected by only a builder and construction workers, it will take a long time and cost a lot of money. With soyo, at least, these expenses are reduced" (Interview at Pesanggrahan, 2020).

The foundation of noble values as the basis for the soyo practice shows the community's commitment to continuing this tradition that has been inherited for a long time. Also, it tries to provide an alternative solution to the "financial" problems that have been experienced by many Pesanggrahan residents in completing the construction of their homes.

\section{The Impact of The Soyo Practice on Community Independence}

In the soyo practice, community members with insufficient funds or goods can contribute their energy as labor. Therefore, it is not uncommon for the composition of craftsmen and construction workers in soyo to be at 3:10, meaning that three people are paid as professionals, while ten of them contribute their labor and expertise voluntarily. Soyo has empowered residents to build houses without government intervention. The problem of innovating homes can be solved by the community, which generally require a lot of funds can be rectified in the spirit of mutual cooperation. This can be done without the need for loans from banking or non-banking financial institutions, as has been performed by other communities in the modern era. Sumadi, a community leader in Pesanggrahan hamlet commented that:

"Anyway, there are many benefits of soyo... Generally, it relates to the number of people and the cost to build the house, from construction to materials. Alhamdulillah, none of the Pesanggrahan residents have a headache thinking about bank debts that may be incurred to build these houses. For example, there are thirteen builders and construction workers, only three are paid professionally, while the rest voluntarily take part in soyo, and other persons later contribute money, cement, sand, iron, and other materials."

Soyo culture and activities have proven to increase independence in fulfilling communal needs and solving problems, not only individually as exemplified above, but institutionally as well. It is common for the government to change their role in the development of housing, education, places of worship, and public road facilities for communities, as well as the fulfillment of people's basic needs, such as water. This is supported by the fact in the field, the government allocated a house renovation program for the Pesanggrahan hamlet community at Batu City to occur only twice or in two homes in a year. The program is funded with Rp. 30 million / house while the community performs soyo activities almost weekly, particularly on Saturdays and Sundays. These activities include building or renovating houses and worship places, such as a mushola or mosque, as well as educational facilities or public amenities, such as roads. Furthermore, this community independently fulfills one basic need, which is the provision of water, by creating a kind of "PDAM Desa" or "Village Water" through soyo practices. The Mayor of Batu Dewanti Rumpoko, in a review of this tradition, said:

"The government is very grateful to the Pesanggrahan hamlet residents because, with soyo, they have contributed to the success of the program by solving problems in residents' houses, providing clean water, building educational and religious facilities, as well as repairing roads."

Furthermore, the community stays organized by following a habitual pattern. Since the essence of soyo is to help others selflessly and collectively, there is an unwritten but well-developed division of community roles based on the capacities and abilities of each citizen. These persons are either considered as sufficiently rich to automatically help with money or goods or as not wealthy enough to assist economically and so will help with labor. Also, this work mechanism shows a well-functioning community system, which will ultimately lead to the building of a stronger cohesion. This is followed by a cultural awareness related to the importance of togetherness in overcoming a problem. A similar situation was seen when residents worked together to build a house for a citizen named Qodir, and this individual's experience was narrated:

"When I built a house, there was no need for soyo to form a mutual cooperation committee. A notification about the event and the house owner during the tahlilan activity at the mosque was enough. Then, those that had money donated cash or building materials, while those without funds contributed labor, and when the construction had ended, everyone disbanded."

\section{DISCUSSIONS}

Communal behavior is not only found in the practices of rural societies but also in current urban cultures. Meanwhile, communalism is reflected in the helping behavior based on togetherness and socialism and not on economic capital or money. The mutual help behavior unconditionally fosters togetherness, which in essence is also part of the implementation of religious values. Therefore, the soyo practice shows the existence of a mutual assistance tradition that continues amidst more materialistic times and also affirms the presence of a cultural mechanism in an urban society.

Communal relations, such as soyo activities, are still existent and needed in the era of modern management in urban societies, and this can become a platform for the development of help-to-help and mutual cooperation behavior among members. In this case, the traditional factor 
[44] has a very important role in maintaining and preserving this cooperation culture in soyo activities. Furthermore, several values of local wisdom were found to be contained in this tradition, such as religion, togetherness, tolerance, and happiness, and this made it sustainable in the community [3]. With soyo activities, people desire to work together to help others, therefore, the tradition is not just cooperation, but also "kerjarasa." It has also proven to increase the community's independence in fulfilling their needs and solving problems. Therefore, many basic societal needs, related to housing, educational facilities, places of worship, and public facilities, such as roads and the provision of clean water can be solved with soyo activities.

Theoretically, cooperation is the main principle in modern management systems that were developed from the classic form initiated by [35] and [13]. This research showed that the communal system is capable of fortifying the noble values and local wisdom, which have been adhered to from one generation to another amid modernization. Therefore, these research results are different from that of [16] regarding the tradition of "sambatan gawe umah," meaning mutual cooperation to build houses in several Muslim communities. These include Karang hamlet, Girikarto village, Panggang, and Gunung Kidul districts. The findings confirmed that the development of sambatan or gotong royong is gradually changing and getting dimmer with the presence of a modernization system in all levels of society, including rural communities. In other studies, such as those by [30] and [34], the values of religion and togetherness strongly influenced the existence of a culture of mutual help and cooperation. However, in this research, togetherness is not only interpreted as mere cooperation but as "kerjarasa."

This research further emphasizes the importance of revitalizing local wisdom values in communities that have adopted a modern management system. Internalization of religion, togetherness, tolerance, and solidarity should be implemented in real terms within everyday life to form a communal society. In fact, soyo will be more interesting when it can be applied in a broader organizational context, as well as in formal and informal community institutions in the society. This is because the concept has proven to be capable of making the achievement of goals easier, cheaper, more effective, and efficient, which are the main characteristics of modern management systems [33]. It has also become a solution and an alternative to the role of formal institutions. Therefore, rather than being weak and helpless when the government is absent during development, the community will replace the roles of the state with local wisdom [19].

\section{CONCLUSION}

The assumption that communal practices based on social values can only be found in rural societies is not always correct, as similar functions are performed in urban areas. Therefore, the activities of the Pesanggrahan Hamlet community in Batu City are important occurrences that reaffirm the ongoing process of strengthening collectivity. These events also find answers related to the revival of awareness on the importance of solidarity and togetherness. The disappearance of social ties, especially in urban communities, due to the influence of modernity has made the culture of mutual help disappear. Soyo is a medium that is capable of bridging people's desire to help each other and is also a sign of the preservation of local values, which are laden with functional moral messages. One of the functions of this tradition lies in the ability to unite urban communities.

Local wisdom as the basis of societal values places communalism as the foundation of this activity and provides space for the development of new models related to the sustainability of traditions in urban communities. Societal activities emphasize the meaning of local community mechanisms that have begun to fade through the soyo practice. The modern management system also has relevance to this tradition where there is a division of labor, even though the regulation is undocumented. Soyo's "local" management reiterates that the practice of togetherness, which is based on social ties, is more capable of answering the challenges in the modern era that tend to independently fulfill personal needs without involving other parties culturally.

The limitation of this research was the object, which was urban communities that tend to be culturally and religiously homogeneous. Almost all residents of the Pesanggrahan hamlet are followers of the Javanese ethnic-Muslim religion, and these people strongly uphold their cultural traditions and are known to be devout in worship. This limitation is expected to become a basis for further research in heterogeneous communities in urban areas with more complex ethnic and religious backgrounds, such as those in big cities. Furthermore, this research can be a basis for development in the context of modern formal institutions, such as companies, non-profit and franchise organizations, as well as educational and social institutions that formally implement modern management systems.

\section{REFERENCES}

[1] Abrar-Ul-Haq, M., Jali, M. R. M., \& Islam, G. M. N. (2018). The development of household empowerment index among rural household of Pakistan. Pertanika Journal of Social Sciences and Humanities.

[2] Acuña Mora, M., Sparud-Lundin, C., Burström, Å., Hanseus, K. Rydberg, A., Moons, P., \& Bratt, E. L. (2019). Patient empowerment and its correlates in young persons with congenital heart disease. European Journal of Cardiovascular Nursing https://doi.org/10.1177/1474515119835434.

[3] Aghsari, D., Wekke, I. S., \& Abbas, N. (2018). Harmony of Coastal Community Regarding Its Ethnic Religion and Cultural Diversity. IOP Conference Series: Earth and Environmental Science. https://doi.org/10.1088/1755-1315/156/1/012034.

[4] Amdam, R. (2010). Empowerment Planning in Regional Development. European Planning Studies. https://doi.org/10.1080/09654313.2010.512165.

[5] Anamofa, J. N. (2018). Kearifan Lokal Guna Pemecahan Masalah.

[6] Baharun, H., Ulum, M. B., \& Azhari, A. N. (2018). Nilai-nilai Pendidikan Islam dalam Tradisi Ngejot: Konsep Edukasi dalam Membangun Keharmonisan dan Kerukunan Antarumat Beragama Berbasis Kearifan Lokal. Fenomena, 10 (1), 1-26.

[7] Bakri, H. (2015). Resolusi Konflik Melalui Pendekatan Kearifan Lokal Pela Gandong di Kota Ambon. The Politics: Jurnal Magister Ilmu Politik Universitas Hasanuddin, 1(1), 51-60.

[8] Bennett, J. E. (2013). Institutions and Governance of Communal Rangelands in South Africa. African Journal of Range and Forage Science. https://doi.org/10.2989/10220119.2013.776634.

[9] Brata, I. (2016). Kearifan Budaya Lokal Perekat Identitas Bangsa. Jurnal Bakti Saraswati. 
[10] Chomba, S. W., Nathan, I., Minang, P. A., \& Sinclair, F. (2015). Illusions of empowerment? Questioning policy and practice of community forestry in Kenya. Ecology and Society. https://doi.org/10.5751/ES-07741-200302.

[11] Community Empowerment Based Local Wisdom in Tourism of Bajo Community, Wakatobi. (2017). International Journal of Scientific \& Technology Research.

[12] Ezeanya, C. (2014). Indigenous Knowledge, Economic Empowerment and Entrepreneurship in Rwanda: The Girinka Approach. The Journal of Pan African Studies (Online).

[13] Fayol, Heni (1946). Administration Industrielle et Generale. Translated by C. Storrs; General and Industrial Management. London. Sir Isaac Pitnam \& Son.

[14] Febryano, I. G., Suharjito, D., Darusman, D., Kusmana, C., \& Hidayat, A. (2014). The roles and sustainability of local institutions of mangrove management in Pahawang Island. Jurnal Manajemen Hutan Tropika. https://doi.org/10.7226/jtfm.20.2.69.

[15] Hamdani Harahap, R., \& Humaizi, H. (2018). Local wisdom in preservation of Lake Toba ecosystems (study on Toba Lake community in the Village of Silalahi I, Sub District of Silahisabungan, Dairi Regency, North Sumatera Province). IOP Conference Series: Earth and Environmental Science. https://doi.org/10.1088/1755-1315/126/1/012122.

[16] Haryani, Heti. (2015). Tradisi Sambatan Gawe Umah pada Masyarakat Muslim Dusun Karang Desa Girikarto Kecamatan Panggang Kabupaten Gunung Kidul. Skripsi. Fakultas Ushuluddin dan Pemikiran Islam, UIN Sunan Kalijaga; Yogyakarta.

[17] Haryanto, J. T. (2014). Kearifan Lokal Pendukung Kerukunan Beragama Pada Komuntias Tengger Malang Jatim. Analisa. https://doi.org/10.18784/analisa.v21i02.15.

[18] Hilman, I., Hendriawan, N., \& Sunaedi, N. (2019). Culture of Local Wisdom of Kampung Kuta Community in Facing Climate Changes in Ciamis Regency, West Java. IOP Conference Series: Earth and Environmental Science. https://doi.org/10.1088/17551315/338/1/012006.

[19] Kamoto, J., Clarkson, G., Dorward, P., \& Shepherd, D. (2013). Doing more harm than good? Community based natural resource management and the neglect of local institutions in policy development. Land Use Policy. https://doi.org/10.1016/j.landusepol.2013.06.002.

[20] Kurniawan, F. (2019). Lejong Tau, A Diorama of Conflict Resolution Based on Local Wisdom. Jurnal Partisipatoris. https://doi.org/10.22219/jp.v1i1.7789.

[21] Kurniawati, W., Mussadun, Suwandono, D., \& Islamey, T. Z. (2019). Local Wisdom in Malay Kampung Semarang as Representatives of Smart Environment. IOP Conference Series: Earth and Environmental Science. https://doi.org/10.1088/1755-1315/396/1/012004.

[22] Lawer, E. T., Lukas, M. C., \& Jørgensen, S. H. (2017). The Neglected Role of Local Institutions in The 'Resource Curse' Debate. Limestone Mining in The Krobo Region of Ghana. Resources Policy. https://doi.org/10.1016/j.resourpol.2017.08.005.

[23] Malakar, Y. (2012). Increasing Adaptive Capacity: What Is the Role of Local Institutions? Risk, Hazards \& Crisis in Public Policy. https://doi.org/10.1002/rhc3.18.

[24] Marasabessy, S., Abdulmudy, R., \& Umanailo, M. C. B. (2020). Factors that influence the success of rural women empowerment in salahutu district. Proceedings of the International Conference on Industrial Engineering and Operations Management.

[25] Marschke, M., Lykhim, O., \& Kim, N. (2014). Can local institutions help sustain livelihoods in an era of fish declines and persistent environmental change? A Cambodian case study. Sustainability (Switzerland). https://doi.org/10.3390/su6052490.

[26] Maryani, E., \& Yani, A. (2016). Local Wisdom of Kampung Naga in Mitigating Disaster and its Potencies for Tourism Education. Man in India.

[27] Nesi, A., \& Rahardi, R. K. (2019). Nilai-Nilai Kearifan Lokal dalam Tradisi Lisan Takanab: Kajian Ekolinguistik. Jurnal Pendidikan Dan Kebudayaan Missio, 11(1), 71-90.

[28] Pornpimon, C., Wallapha, A., \& Prayuth, C. (2014). Strategy Challenges the Local Wisdom Applications Sustainability in Schools. Procedia - Social and Behavioral Sciences. https://doi.org/10.1016/j.sbspro.2014.01.1210.

[29] Primyastanto, M., Muhammad, S., Efani, A., Street, V., \& Street, V. (2013). Fisheries Resources Management by Empowering the Local Wisdom in Madura Straits. 3(6), 13-21.

[30] Putra, Adi M.; Bahtiar dan Upe, Ambo. (2018). Eksistensi Kebudayaan Tolong Menolong (Kaseise) sebagai Bentuk Solidaritas Sosial pada Masyarakat Muna (Studi di Desa Mataindaha Kecamatan Pasikolaga). Neo Societal; Vol. 3; No. 2, ISSN: 2503-359X; Hal. 479483.
[31] Ratnawati, S., Jurianto, J., \& Ali, M. (2017). Jhemo Madura: Kearifan Lokal dalam Tantangan Global.

[32] Renjaan, M. J., Purnaweni, H., \& Anggoro, D. D. (2013). Studi Kearifan Lokal Sasi Kelapa Pada Masyarakat Adat di Desa Ngilngof Kabupaten Maluku Tenggara. Jurnal Ilmu Lingkungan, 11(1), 23-29.

[33] Robbin, Stephen P. Mary, Coulter (2016). Management. Pearson Education, Inc.

[34] Rolitia, Meta; Achdiani, Yani dan Eridiana, Wahyu. 2016. Nilai Gotong Royong untuk Memperkuat Solidaritas dalam Kehidupan Masyarakat Kampung Naga. Jurnal Pendidikan Sosiologi UPI, Vol. 6 No. 1.

[35] Taylor, Frederick Winslow (2011), Principles of Scientific Management. New York. Harper.

[36] Triadiyatma, A. (2016). Model Penyelesaian Konflik Nelayan Berbasis Kearifan Lokal Sebagai Modal Sosial di Kecamatan Lekok Kabupaten Pasuruan (Doctoral dissertation, Universitas Airlangga).

[37] Uge, S., Neolaka, A., \& Yasin, M. (2019). Development of social studies learning model based on local wisdom in improving students' knowledge and social attitude. International Journal of Instruction. https://doi.org/10.29333/iji.2019.12323a.

[38] Vitasurya, V. R. (2016). Local Wisdom for Sustainable Development of Rural Tourism, Case on Kalibiru and Lopati Village, Province of Daerah Istimewa Yogyakarta. Procedia - Social and Behavioral Sciences. https://doi.org/10.1016/j.sbspro.2015.12.014.

[39] Widhianthini. (2017). A dynamic model for sustainable tourism village planning based on local institutions. Journal of Regional and City Planning. https://doi.org/10.5614/jrcp.2017.28.1.1.

[40] Widjajanti, K. (2011). Model Pemberdayaan Masyarakat. Jurnal Ekonomi Pembangunan: Kajian Masalah Ekonomi Dan Pembangunan. https://doi.org/10.23917/jep.v12i1.202.

[41] Wig, T., \& Tollefsen, A. F. (2016). Local institutional quality and conflict violence in Africa. Political Geography. https://doi.org/10.1016/j.polgeo.2016.01.003.

[42] Yuliana, Sriyati, S., \& Sanjaya, Y. (2017). Local wisdom of Ngata Toro community in utilizing forest resources as a learning source of biology. AIP Conference Proceedings. https://doi.org/10.1063/1.4995217.

[43] Zuhdi, M. H. (2018). Kearifan Lokal Suku Sasak sebagai Model Pengelolaan Konflik di Masyarakat Lombok. Mabasan, 12(1).

[44] Zulfadrim, Z., Toyoda, Y., \& Kanegae, H. (2018). The implementation of local wisdom in reducing natural disaster risk: A case study from West Sumatera. IOP Conference Series: Earth and Environmental Science. $\quad$ https://doi.org/10.1088/17551315/106/1/012008.

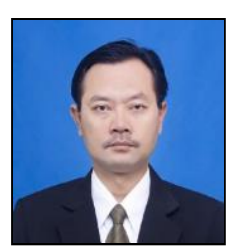

Dr. Misbahul Munir is Associate Professor at Economics Faculty, UIN Maulana Malik Ibrahim Malang. He received doctoral degree from Doctoral Program in Economics from Brawijaya University, Malang, Indonesia

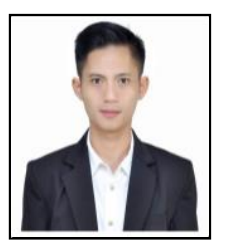

Dr. Basir. $\mathbf{S}$ is a Lecturer at the School of Strategic and Global Studies, Universitas Indonesia. He received doctoral degree Doctoral Program in Management from Brawijaya University, Malang, Indonesia

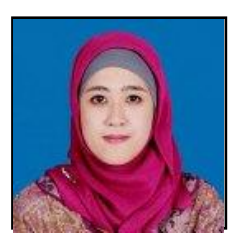

Dr. Maretha Ika Prajawati is a Lecturer at Economics Faculty, UIN Maulana Malik Ibrahim Malang. She received doctoral degree from Doctoral Program in Economics Education from Universitas Negeri Malang, Indonesia 